\title{
Peningkatan Keterampilan Berbicara Bahasa Indonesia Subtema Kebersamaan Di Tempat Wisata Melalui Penerapan Metode Demonstrasi
}

\section{Restu Aji Puryanto1*, I Gusti Ngurah Japa²}

\author{
${ }^{12} J u r u s a n$ Pendidikan Bahasa Inggris Universitas Pendidikan Ganesha
}

\section{A R T I C L E I N F O}

Article history:

Received January 21, 202

Revised February 03, 2021

Accepted April 08, 2021

Available online May 25, 2021

\section{Kata Kunci:}

Keterampilan berbicara

bahasa Indonesia, metode demonstrasi, dan kelas II SD.

Keywords:

Speaking, Bahasa Indonesia Demonstration method, $2^{\text {nd }}$ graders

\begin{abstract}
A B S T R A K
Penelitian ini bertujuan untuk meningkatkan keterampilan berbicara melalui metode demonstrasi mata pelajaran Bahasa Indonesia pada siswa kelas II SD Negeri 1 Banjar Jawa semester II tahun ajaran 2018/2019. Penelitian ini merupakan Penelitian Tindakan Kelas menggunakan model spiral dari Kemmis dan Mc. Taggart melalui 2 siklus. Dalam setiap siklus memiliki 4 tahap yakni perencanaan, tahap pelaksanaan, observasi, dan refleksi. Instrumen yang digunakan berupa lembar observasi keaktivan siswa dan tes unjuk kinerja. Teknik analisis data menggunakan analisis deskriptif kuantitatif. Hasil penelitian ini menunjukkan bahwa penerapan metode demonstrasi dapat meningkatkan keterampilan berbicara siswa kelas II SD. Pada pra siklus dan siklus I sebesar $12.5 \%$ yaitu pada tahap pra siklus terdapat 16 siswa (50\%) sedangkan pada siklus I terdapat 20 siswa $(62,5 \%)$ yang mencapai nilai tuntas. Pada siklus I dan siklus II mengalami peningkatan sebesar $13,75 \%$. Hal tersebut dilihat dari hasil siklus I terdapat 20 siswa $(62,5 \%)$ dan pada siklus II terdapat 25 siswa $(76,25 \%)$ yang mencapai nilai tuntas.
\end{abstract}

\section{$A B S T R A C T$}

The study was meant to improve student's speaking skill through the implementation of demonstration method. The setting was taken in SD Negeri 1 Banjar Jawa on Bahasa Indonesia subject. 32 students of grade $2^{\text {nd }}$ were chosen as subjects of study. Classroom action research was chosen as research model. The research model was chosen from Kemmis and Mc. Taggart spiral cycle model. There were 4 stages in every cycle which are Planning, Acting, Observing, and Reflecting. Student's activity observation sheet and performance test were chosen as research instruments. The data analysis was quantitative description. The result of the study showed that the implementation of demonstration method could improve $2^{\text {nd }}$ graders' speaking skill. In pre-cycle and cycle 1 , the score gap was $12.5 \%$. There are 16 students (50\%) and there are 20 students (62.5\%) in cycle 1 which reach minimum standard score. Therefore, there was improvement in cycle to for $13.75 \%$. This number were shown from result that there are 20 students (62.5\%) in cycle 1 and 25 students (76.25\%) which reached standard score.

\section{Pendahuluan}

Pendidikan dan pengajaran adalah suatu proses yang sadar tujuan. Tujuan dapat diartikan sebagai suatu usaha untuk memberikan rumusan hasil yang diharapkan siswa setelah melaksanakan pengalaman belajar Tercapai tidaknya tujuan pengajaran salah satunya adalah terlihat dari prestasi belajar yang diraih siswa. Dengan prestasi yang tinggi, para siswa mempunyai indikasi berpengetahuan yang baik (Pratama, Firman and Neviyarni, 2019)Pendidikan juga merupakan suatu cara pembentukan kemampuan manusia untuk menggunakan akal fikiran/rasional mereka sebagai jawaban dalam menghadapi berbagai masalah yang timbul di masa yang akan datang. Pendidikan sering dikaitkan dengan usaha untuk menciptakan sumber daya manusia dapat menghadapi tantangan global yang sangat pesat. Dengan pendidikan yang baik kita akan mudah mengikuti perkembangan zaman di masa yang akan datang. Kegiatan mendidik dapat dilakukan melalui jalur formal, non formal, dan informal. Salah satu usaha pemerintah yang dilakukan untuk meningkatkan sumber daya manusia yaitu melalui pendidikan formal. Pendidikan formal di Indonesia diawali dengan jenjang pendidikan dasar yang bertujuan untuk mengembangkan sikap dan kemampuan serta memberikan kemampuan serta memberikan pengetahuan dan ketrampilan dasar yang diperlukan untuk hidup di dalam masyarakat serta mempersiapkan peserta didik yang memenuhi persyaratan untuk mengikuti pendidikan menengah (UU No 19 Tahun 1989 Pasal 13) Pendidikan usia SD disamping mengembangkan potensi akademik dibidang ilmu pengetahuan tetapi juga memiliki peran dalam mengasah keterampilan-keterampilan siswa untuk dapat berperan di dalam masyarakat. Keterampilan dasar yang harus dikuasai oleh siswa agar dapat perperan di masyarakat 
adalah keterampilan untuk berkomunikasi. Pengertian pendidikan dalam lingkungan sekolah mempunyai arti yang lebih luas dari pada mengajar. Mengajar lebih difokuskan pada proses transformasi pengetahuan yang bersifat afektif. Pendidikan merupakan proses komunikasi dua arah yang tidak hanya merupakan proses transformasi pengetahuan tetapi juga 2 proses internalisasi nilai-nilai karakter. Karakter dari masing-masing siswa berbeda-beda dan harus dikuasai oleh seorang guru apabila ingin proses belajar mengajar di dalam kelas dapat berhasil. Hal itu merupakan tugas guru untuk memahami masing-masing karakter siswa karena setiap siswa memiliki cara yang berbeda dalam memahami dan menguasai materi yang disampaikan oleh guru. Pembelajaran bahasa Inggris sangat penting untuk diterapkan dalam suatu sekolah. Siswa diharapkan dapat menguasai bahasa Inggris dengan baik. Proses pembelajaran dari pengenalan, pemahaman, penerapan dalam kehidupan sehari hari sangat di butuhkan guna mencapai pembelajaran bahasa Inggris yang ideal. Pembelajaran penguasaan kosakata termasuk dalam penguasaan bahasa. Penguasaan bahasa mencakup berbagai keterampilan yaitu keterampilan mendengar, keterampilan berbicara, keterampilan membaca dan keterampilan menulis (Novianti, 2020).

Berbagai teori yang dikembangkan saat ini telah mewarnai proses dan praktik pendidikan. Sumbangsih para tokoh dalam menciptakan teori telah memberikan perkembangan dan kemajuan dalam proses pendidikan. Lahirnya teori dalam bidang pendidikan memberikan warna baru terhadap sistem pendidikan, proses belajar mengajar, manajemen sekolah dan metode pembelajaran. Adanya pergeseran metode dan pola didik pengajar terhadap peserta didik merupakan proses dari pelaksanaan teori dalam bidang pendidikan. Sebagai contoh berkembangnya pola pendidikan active learning dimana proses pembelajaran tidak hanya terpusat pada pengajar akan tetapi peserta didik mempunyai peranan sangat menentukan hasil belajar. Hal ini dipelopori oleh teori yang berkembang yaitu teori behaviorisme dimana setiap manusia mempunyai kemampuan untuk berfikir dan melakukan setiap aktifitas dalam proses belajar (Sholichah, 2018). Menurut Stewart dan Kenner Zimner (Zamzani., 1997) memandang bahwa kebutuhan akan berkomunikasi yang efektif dianggap sebagai suatu yang esensial untuk mencapai keberhasilan dalam setiap individu, baik itu aktivitas individu ataupun kelompok. Kecakapan siswa dalam berkomunikasi ditentukan oleh keterampilan berbicara siswa.

Pembelajaran bahasa Indonesia merupakan serangkaian aktivitas yang dilakukan siswa untuk mencapai keterampilan berbahasa tertentu. Menurut Abidin (2012: 82) pembelajaran bahasa adalah pembelajaran yang harus mampu menyajikan sejumlah stimulus yang baik guna menghasilkan respon yang berkualitas serta telah mengeluarkan respon tersebut. Pembelajaran bahasa Indonesia selalu menggunakan teks untuk sarana pembelajaran sejalan pula dengan Kurikulum 2013 yakni pembelajaran berbasis teks. Pembelajaran berbasis teks menuntut siswa menggunakan bahasa tidak hanya sarana komunikasi, tetapi juga sebagai sarana untuk mengembangkan kemampuan berfikir. Menurut Ramadania dalam pembelajaran berbasis teks, yakni bahasa Indonesia diajarkan bukan sekadar pengetahuan bahasa, melainkan sebagai teks yang mengemban fungsi untuk menjadi sumber aktualisasi diri penggunanya pada konteks sosial, budaya, dan akademis (Perayani, dkk, 2020)

Keterampilan berbicara merupakan salah satu aspek keterampilan dasar dalam berbahasa. Menurut M. Soenardi Djiwandono (1991: 68), berbicara merupakan kegiatan berbahasa yang aktif dari seorang pemakai bahasa, yang menuntut prakarsa nyata dalam penggunaan bahasa untuk mengungkapkan diri secara lisan. Keterampilan berbicara digunakan untuk mengungkapkan ide, gagasan, ataupun ungkapan kepada orang lain sehingga mudah dimengerti/ dipahami dengan baik. Sabarti Akhadiah, dkk (1992/1993: 153) mengemukakan bahwa berbicara adalah peristiwa proses penyampaian pesan secara lisan oleh pembicara kepada penerima pesan. Dengan kata lain, berbicara adalah menyampaikan pesan melalui bahasa lisan.

Keterampilan berbicara bukanlah suatu proses yang bersifat pasif, melainkan suatu proses aktif yang membutuhkan daya berpikir yang logis dan sistematis. Oleh karena itu Hal ini dipertegas oleh pernyataan Yeager (Ahmad Rofi'uddin dan Darmiyati Zuhdi., 1998) dalam berbicara, siswa harus dapat membedakan fakta dan pendapat, mengenal hubungan sebab akibat, menyatakan argumen, dan sebagainya. Dalam pembelajaran Bahasa pada usia sekolah dasar keterampilan berbicara berperan sebagai keterampilan yang menunjang ketrampilan berbahasa yang lain yaitu menyimak, membaca, menulis. Peranan berbicara sangat besar, baik dalam mata pelajaran bahasa Indonesia maupun dalam kehidupan sehari-hari. Keterampilan berbicara perlu diajarkan sejak dini agar siswa memiliki rasa percaya diri untuk berbicara dalam menjalin komunikasi sebagai syarat untuk mentransfer ilmu baik dilingkungan sekolah maupun di dalam masyarakat. Hal ini perlu diperhatikan oleh guru agar siswa dapat lebih lancar dan fasih dalam berbicara.

Rendahnya keterampilan berbicara siswa berakibat pada kesulitan siswa dalam mengungkapkan suatu ide, gagasan, dan pendapat. Dalam proses pembelajaran siswa akan mengalami kesulitan untuk berkomunikasi, bertanya, menjelaskan, dan menafsirkan makna pembicaraan. Menurut (Haryadi dan Zamzani, 1996/1997: 17) pembelajaran berbicara adalah utama dan pokok setelah proses menyimak 
yaitu 42\% kegiatan menyimak, 32\% berbicara, 15\% membaca, dan 11\% menulis. Berdasarkan hal itu, keberhasilan dari tujuan pembelajaran bahasa sangat ditentukan oleh komunikasi yang efektif dimana keterampilan berbicara siswa sangat diperlukan dalam proses pembelajaran.

Berdasarkan hasil observasi pada kelas 2 SD Negeri 1 Banjar jawa ditemukan bahwa keterampilan berbicara masih cukup rendah. Proses pembelajaran berlangsung pasif, mereka hanya mendengarkan, tanpa bertanya. Siswa kurang percaya diri dalam bertanya dan mengemukakan pendapat. Padahal pembelajaran yang baik adalah jika terjalin komunikasi dua arah yaitu siswa dan guru. (Wuryandani., 2011) mengatakan dalam proses belajar mengajar, akan terjadi interaksi antara pendidik dengan peserta didik. Rendahnya keterampilan berbicara siswa juga terlihat pada minimnya nilai ketuntasan siswa dalam penilaian keterampilan berbicara yang tidak mencapai KKM. Berdasrakan hasil observasi yang di lakukan di kelas 2 ditemukan fakta bahwa lebih dari 75\% belum mencapai KKM.yang telah ditetapkan sekolah yaitu 75. Penilian keterampilan berbicara terlihat pada ketercapaian indicator indikator, diantaranya adalah kelancaran berbicara, ketepatan pilihan kata (diksi), struktur kalimat, intonasi membaca kalimat dan ekspresi.

(Daryanto, 2012) menyatakan bahwa guru memiliki peran yang sangat penting dalam menentukan kualitas dan kuantitas pengajaran yang dilaksanakan. Oleh karena itu, guru dituntut untuk dapat menjalankan tugas dengan sebaik-baiknya. Untuk dapat mencapai tujuan pengajaran yang diharapkan, guru harus pandai memilih metode yang tepat dan sesuai dengan kebutuhan anak didik supaya anak didik merasa senang dalam belajar. Upaya peningkatan keterampilan berbahasa pada anak SD kelas 2 yang lebih menekankan pada pembentukan mental dan kepercaya dirianya, maka guru harus menunjukkan, memperlihatkan sesuatu proses (relevan dengan pokok bahasan atau materi yang sedang disajikan), sehingga seluruh siswa dalam kelas dapat melihat, mengamati, mendengar, dan merasakan proses yang dipertunjukkan oleh guru tersebut. Berdasarkan permasalahan diatas dapat disimpulkan salah satu faktor yang dapat meningkatkan keterampilan berbicara siswa adalah penggunaan metode yang tepat yaitu demonstrasi.

Menurut Udin (2004:424) "Metode demonstrasi adalah cara penyajian pelajaran dengan mempertunjukkan secara langsung objek atau cara melakukan sesuatu untuk mempertunjukkan proses tertentu". (Djamarah, Bahri, 2000) menyebutkan "Metode demonstrasi adalah metode yang digunakan untuk memperlihatkan suatu proses atau cara kerja suatu benda yang berkenaan dengan bahan pelajaran". Dengan menerapkan metode demonstrasi siswa dapat memupuk rasa percaya diri dalam berkomunikasi dengan menggunakan Bahasa Indonesia yang baik dan benar. Penggunaan metode ini juga dimaksudkan untuk membantu siswa agar lebih berani dalam melakukan komunikasi secara lisan dengan menggunakan Bahasa Indonesia yang baik sehingga keterampilan berbicara akan semakin terasah.

Berdasarkan permasalahan dan penguraian tersebut, diperlukan dilakukan penelitian tindakan kelas tentang penggunaan metode demonstrasi untuk meningkatkan keterampilan berbicara siswa. Oleh karena itu peneliti melakukan penelitian dengan judul "Peningkatan Keterampilan Berbicara Bahasa Indonesia Subtema Kebersamaan di Tempat Wisata Melalui Penerapan Metode Demonstrasi Pada Siswa Kelas 2 SDN 1 Banjar Jawa".

\section{Metode}

Desain penelitian yang digunakan adalah penelitian tindakan kelas (PTK). Menurut Arikunto (2006: 2), penelitian tindakan kelas merupakan serangkaian kegiatan yang akan kembali ke asal sehingga membentuk suatu siklus. Model penelitian tindakan kelas yang digunakan dalam penelitian ini adalah model spiral yang dikembangkan oleh Kemmis dan Mc. Taggart yaitu model siklus secara berulang dan berkelanjutan. Model ini mencakup empat komponen yaitu perencanaan (planning), tindakan (action), observasi (observation) dan refleksi (reflection).

\section{a. Siklus 1}

1. Perencanaan (Planning)

Beberapa hal yang perlu direncanakan sebelum penelitian adalah sebagai berikut.

a. Menyusun Rencana Pelaksanaan Pembelajaran (RPP) sub tema Kebersamaan di Tempat Wisata mata pelajaran Bahasa Indonesia dengan menerapkan metode demonstrasi.

b. Membuat pedoman observasi yang akan digunakan untuk mengamati aktivitas guru dan aktivitas siswa selama proses pembelajaran.

c. Menyusun alat evaluasi yang akan diberikan setiap akhir siklus.

2. Tindakan (Action)

Pada tahap ini guru kelas mengajar sesuai rencana pembelajaran sub tema Kebersaan di Tempat Wisata mata pelajaran Bahasa Indonesia sederhana dengan menggunakan metode demonstrasi.

3. Observasi (Observation) 
Pada tahap ini, peneliti melakukan pengamatan dan mencatat semua hal-hal yang diperlukan dan terjadi selama pelaksanaan tindakan berlangsung. Pengumpulan data ini dilakukan dengan menggunakan lembar observasi yang telah disusun sebelumnya.

4. Refleksi (Reflection)

Pada tahap refleksi peneliti dan guru kelas melakukan evaluasi terhadap pelaksanaan tindakan yang telah dilakukan. Hasil dari refleksi tersebut digunakan sebagai bahan untuk menyusun kembali rencana tindakan perbaikan yang akan dilaksanakan oleh guru pada siklus berikutnya. Refleksi dilakukan pada setiap akhir siklus tindakan sampai tujuan dari penelitian menunjukkan keberhasilan.

\section{b. Siklus 2}

Skenario tindakan dalam siklus II disusun berdasarkan hasil refleksi dari pelaksanaan tindakan siklus I. Siklus II dilaksanakan untuk memberi penguatan serta untuk memperbaiki hasil pelaksanaan siklus I yang kurang sesuai dengan tujuan dan harapan yang ingin dicapai.

Penelitian akan dilanjutkan pada siklus selanjutnya apabila pada siklus I hasil yang diperoleh belum tercapai secara maksimal. Namun apabila pada siklus I sudah tercapai hasil yang diharapkan maka siklus II hanya dijadikan pemantapan dari siklus sebelumnya. Siklus akan dihentikan ketika tujuan dari penelitian ini sudah tercapai yaitu meningkatnya keterampilan berbicara pada siswa kelas II SD Negeri 1 Banjar Jawa.

\section{Teknik Pengumpulan Data dan Instrumen Penelitian}

Teknik pengumpulan data menggunakan metode observasi dan tes.

a. Observasi

Menurut (Sanjaya, 2006), observasi merupakan teknik mengumpulkan data dengan cara mengamati setiap kejadian yang sedang berlangsung dan mencatatnya dengan alat observasi tentang hal-hal yang akan diamati atau diteliti. Observasi (pengamatan) dalam penelitian ini dilakukan selama berlangsungnya proses pembelajaran matematika dengan menerapkan metode demonstrasi.

\section{b. Tes Unjuk Kerja}

Menurut Anne Anastasi (Sudijono, 2012) tes adalah alat pengukur yang mempunyai standar yang objektif sehingga dapat digunakan secara meluas, serta betul-betul digunakan untuk mengukur dan membandingkan keadaan psikis atau tingkah laku individu.Tes yang digunakan dalam penelitian ini adalah untuk mengukur dan menilai keterampilan berbicara menggunakan metode demonstrasi siswa kelas 2 SD Negeri 1 Banjar Jawa pada pembelajaran bahasa Indonesia tema 7. Kebersamaan subtema 4. Kebersamaan di Tempat Wisata.Sedangkan intrumen yang digunakan dalam penelitian ini adalah tes unjuk kerja.

a. Lembar Observasi

Lembar observasi dalam penelitian ini berupa daftar check list yang terdiri dari lembar observasi kegiatan guru dan lembar observasi kegiatan siswa.

b. Tes Unjuk Kerja

Tes yang digunakan dalam penelitian ini digunakan untuk menilai keterampilan siswa dalam melakukan demonstrasi.

\section{Kriteria Keberhasilan Tindakan}

Keberhasilan suatu tindakan biasanya didasarkan pada sebuah standar yang harus dipenuhi. Tes unjuk kerja dilakukan disetiap akhir siklus. Analisis data dilakukan dengan cara menghitung persentase ketuntasannya. Untuk menghitung persentase ketuntasan dapat dicari dengan menggunakan rumus jumlah siswa yang nilainya lebih dari sama dengan 75 dibagi jumlah siswa dikalikan dengan $100 \%$.

Menurut data, apabila $70 \%$ siswa mendapatkan nilai $\geq 75$ dapat disimpulkan bahwa kriteria keberhasilan tercapai. Namun, apabila $<70 \%$ siswa belum mendapatkan nilai $\geq 75 \%$ maka dibutuhkan siklus selanjutnya sehingga kriteria keberhasilan penelitian dapat tercapai.

\section{Teknik Analisis Data}

Teknik analisis data yang digunakan dalam penelitian ini adalah kualitatif dan kuantitatif. Data hasil observasi aktivitas guru dan siswa dalam penerapan metode demonstrasi dianalisis secara deskriptif kualitatif dan data tes unjuk kerja siswa dianalisis secara deskriptif kuantitatif.

\section{Hasil Dan Pembahasan}

Hasil Peneliti dan guru kelas II melakukan evaluasi proses pembelajaran dengan mengolah dan mendiskusikan hasil pengamatan aktivitas guru dan aktivitas siswa selama pembelajaran berlangsung. 
Hal tersebut bertujuan untuk mengetahui kekurangan dari pembelajaran pada siklus I. Berikut merupakan hasil refleksi dari proses pembelajaran pada siklus I.

1) siswa masih malu, ragu-ragu, dan takut siswa tidak percaya diri untuk berbicara di depan kelas,

2) siswa tidak bisa fokus dalam persiapan maupun padasaat melakukan demonstrasi,

3) siswa kurang lancar, terbata-bata untuk berbicara, dan

4) aspek kebahasaan dalam mendemonstrasikan dialog percakapan yaitu tekanan, ucapan, kosa kata, struktur kalimat dan materi cerita banyak yang kurang tepat.

Rata-rata nilai keterampilan berbicara siswa siswa kelas II SD Negeri 1 Banjar Jawa semester II tahun ajaran 2018/2019 pada siklus I adalah 74,06. Dengan persentase ketuntasan siswa sebesar $69,15 \%$.

Hasil belajar siklus I siswa kelas II SD Negeri 1 Banjar Jawa semester II tahun ajaran 2018/ 2019 sudah baik namun masih terdapat beberapa siswa yang masih belum tuntas, jadi harus ditingkat lagi, hal tersebut disebabkan oleh beberapa hal yaitu (1) siswa kurang memperhatikan saat pembelajaran, (2) Siswa tidak sungguh-sungguh ketika diminta untuk berlatih mendemonstrasikan dialog, dan (3) siswa kurang termotivasi. Kendala tersebut diduga karena kurangnya motivasi siswa dalam belajar, kurangnya bimbingan yang dilakukan oleh guru ketika melakukan demonstrasi, dan guru belum optimal mengelola kelas.

Peneliti dan guru kelas II melakukan evaluasi proses pembelajaran siklus II dengan mengolah dan mendiskusikan hasil pengamatan aktivitas guru dan aktivitas siswa selama pembelajaran berlangsung. Hal tersebut bertujuan untuk mengetahui kekurangan dari pembelajaran pada siklus II. Berikut merupakan hasil refleksi dari proses pembelajaran pada siklus II.

1) Perubahan pada saat perencanaan siklus II. Melalui mengubah topik materi dengan hal yang akrab dengan keseharian siswa, sehingga siswa lebih memahami materi yang dibahas.

2) Memotivasi siswa untuk aktif dan berpartisipasi saat proses pembelajaran.

3) Guru memberikan bimbingan saat proses pembelajaran. Dengan melakukan bimbingan kepada siswa yang mengalami kesulitan belajar membuat kegiatan belajar dapat berjalan dengan efektif.

Setelah dilakukan pembelajaran dengan menerapkan model demontrasi siswa kelas II SD Negeri 1 Banjar Jawa semester II tahun ajaran 2018/ 2019 keterampilan berbicara siswa menjadi meningkat dengan naiknya nilai rata-rata kelas.

Perbandingan rerata hasil belajar pra siklus, siklus I dan siklus II nampak rata-rata dari pra siklus sebesar 69,15 meningkat menjadi 74,06 pada siklus I. Kemudian pada siklus II rata-rata hasil belajar menjadi 74,06.

Hipotesis tindakan penelitian ini terbukti bahwa penerapan metode demonstrasi pada mata pelajaran Bahasa Indonesia subtema Kebersamaan di Tempat Wisata apabila diterapkan secara efektif dan efisien, maka dapat meningkatkan keterampilan berbicara pada siswa kelas II SD Negeri 1 Banjar Jawa semester II Tahun 2018/2019.

\section{Simpulan}

Setelah Berdasarkan hasil penelitian, peningkatan keterampilan berbicara mata pelajaran bahasa Indonesia pada pra siklus dan siklus I sebesar $12.5 \%$ yaitu pada tahap pra siklus terdapat 16 siswa (50\%) sedangkan pada siklus I terdapat 20 siswa $(62,5 \%)$ yang mencapai nilai tuntas. Pada siklus I dan siklus II mengalami peningkatan sebesar $13,75 \%$. Hal tersebut dilihat dari hasil siklus I terdapat 20 siswa $(62,5 \%)$ dan pada siklus II terdapat 25 siswa $(76,25 \%)$ yang mencapai nilai tuntas.

Selain peningkatan persentase jumlah siswa yang mencapai nilai tuntas, peningkatan terjadi pada nilai rata-rata siswa. Nilai rata-rata hasil belajar siswa dari pra siklus dan siklus I mengalami peningkatan sebesar 4,91. Peningkatan tersebut terjadi dengan besaran nilai pada pra siklus sebesar 69,16 dan meningkat pada siklus I menjadi sebesar 74,06 . Peningkatan juga terjadi pada siklus I dan siklus II sebanyak 3,98. Peningkatan terjadi dengan nilai pada siklus I sebesar 74,06 menjadi 78,04.

\section{Daftar Pustaka}

Ahmad Rofi'uddin dan Darmiyati Zuhdi. (1998) Pendidikan Bahasa dan Sastra Indonesia di Kelas Tinggi. Jakarta: Dirjen Dikti.

Daryanto, H. (2012) Evaluasi Pendidikan. Jakarta: Rineka Cipta.

Djamarah, Bahri, S. (2000) Guru dan Anak Didik dalam Interaksi Edukatif. Jakarta: PT. Rineka Cipta.

Novianti, Y. (2020) 'Melalui Penggunaan Media Kartu Gambar Pada Siswa Kelas Vii Smpn 1 Muara Bungo', 5(1), pp. 551-556.

Perayani, dkk, K. (2020) 'Pembelajaran Teks Laporan Hasil Observasi Dengan Metode Cooperative Script di Kelas X IPS 1', Jurnal Pendidikan Bahasa dan Sastra Indonesia, (3), pp. 94-102.

Pratama, F., Firman, F. and Neviyarni, N. (2019) 'Pengaruh Motivasi Belajar Siswa Terhadap Hasil Belajar Ipa Di Sekolah Dasar', Edukatif: Jurnal Ilmu Pendidikan, 1(3), pp. 280-286. doi: 
10.31004/edukatif.v1i3.63.

Sanjaya, W. (2006) Strategi Pembelajaran Berorientasi Standar Proses Pendidikan. Jakarta: Kencana Prenada Media Group.

Sholichah, A. S. (2018) 'Teori-Teori Pendidikan Dalam Al-Qur'an', Edukasi Islami : Jurnal Pendidikan Islam, 7(01), p. 23. doi: 10.30868/ei.v7i01.209.

Sudijono, A. (2012) Pengantar Evaluasi Pendidikan. Jakarta: Rajawali Pers.

Wuryandani., F. dan W. (2011) Pembelajaran PKn di Sekolah Dasar. Yogyakarta: Nuha Litera.

Zamzani., H. dan (1997) Peningkatan Keterampilan Berbahasa Indonesia. Jakarta: Depdikbud. 